\title{
Regional effect on urban atmospheric nucleation
}

\author{
Imre Salma ${ }^{1}$, Zoltán Németh ${ }^{1}$, Veli-Matti Kerminen ${ }^{2}$, Pasi Aalto ${ }^{2}$, Tuomo Nieminen ${ }^{2}$, Tamás Weidinger ${ }^{3}$, \\ Ágnes Molnár ${ }^{4}$, Kornélia Imre ${ }^{4}$, and Markku Kulmala ${ }^{2}$ \\ ${ }^{1}$ Institute of Chemistry, Eötvös University, 1518 Budapest, P.O. Box 32, Hungary \\ ${ }^{2}$ Department of Physics, 00014 University of Helsinki, Helsinki, P.O. Box 64, Finland \\ ${ }^{3}$ Department of Meteorology, Eötvös University, 1518 Budapest, P.O. Box 32, Hungary \\ ${ }^{4}$ MTA-PE Air Chemistry Research Group, 8201 Veszprém, P.O. Box 158, Hungary \\ Correspondence to: Imre Salma (salma@chem.elte.hu)
}

Received: 3 February 2016 - Published in Atmos. Chem. Phys. Discuss.: 5 April 2016

Revised: 9 June 2016 - Accepted: 27 June 2016 - Published: 18 July 2016

\begin{abstract}
Secondary aerosol particle production via new particle formation (NPF) has been shown to be a major contributor to the global aerosol load. NPF has also been observed frequently in urban environments. Here, we investigate the effect of regional NPF on urban aerosol load under well-defined atmospheric conditions. The Carpathian Basin, the largest orogenic basin in Europe, represents an excellent opportunity for exploring these interactions. Based on longterm observations, we revealed that NPF seen in a central large city of the basin (Budapest) and its regional background occur in a consistent and spatially coherent way as a result of a joint atmospheric phenomenon taking place on large horizontal scales. We found that NPF events at the urban site are usually delayed by $>1 \mathrm{~h}$ relative to the rural site or even inhibited above a critical condensational sink level. The urban processes require higher formation rates and growth rates to be realized, by mean factors of 2 and 1.6, respectively, than the regional events. Regional- and urban-type NPF events sometimes occur jointly with multiple onsets, while they often exhibit dynamic and timing properties which are different for these two event types.
\end{abstract}

\section{Introduction}

New aerosol particle formation (NPF) and consecutive particle growth processes in the atmosphere (Kulmala et al., 2013) were first identified in clean environments (Weber et al., 1995; Mäkelä et al., 1997), and the NPF occurrence frequency and its contribution to particle number concentrations were later found to be substantial in the global troposphere
(Kulmala et al., 2004; Spracklen et al., 2006). Particles originating from these processes affect the Earth's radiation balance mainly by acting as cloud condensation nuclei $(\mathrm{CCN}$; Kerminen et al., 2012; Carslaw et al., 2013), and their contribution to the total number of $\mathrm{CCN}$ can be up to $50 \%$ or even more (Merikanto et al., 2009). Recently, NPF has been proved to be common in polluted environments, including large cities (Woo et al., 2001; Baltensperger et al., 2002; Alam et al., 2003; Wehner et al., 2004; Salma et al., 2011; Dall'Osto et al., 2013; Xiao et al., 2015) as well. The connections between the urban and regional air, including air pollution and climate, have remained unknown despite the fact that NPF and particle growth driven by regional air masses can also interact with urban climate and can contribute to the public's excess health risk from nanoparticle exposure (Salma et al., 2014, 2015).

The Carpathian Basin offers excellent conditions for atmospheric studies on interactions between regional and urban NPF processes because of its extension, moderate climate and topographically discrete character and because it contains a large city, Budapest, at its central part. We characterized atmospheric conditions of the city centre and nearcity background of Budapest by performing continuous measurements of aerosol, air pollutant gases and meteorological data for two 1-year-long time intervals. We completed similar measurements in the rural background at the K-puszta station, representing the regional atmospheric conditions over the same time intervals. The major objectives of the present paper are to identify and quantify both important similarities and differences between the urban and regional NPF types and to investigate the interactions and associations between 
urban air in Budapest and regional rural atmosphere in the background of the city with respect to NPF.

\section{Methods}

\subsection{Measurement locations and time intervals}

The Carpathian Basin (also known as the Pannonian Basin) is a topographically discrete unit in the south-eastern part of central Europe surrounded by the Eastern Alps, the Carpathian Mountains, the Balkan Mountains and the Dinaric Alps (Karátson, 2006; Fig. 1). Its typical dimensions in the $\mathrm{N}-\mathrm{S}$ and $\mathrm{W}-\mathrm{E}$ directions are approximately 450 and $650 \mathrm{~km}$, respectively, with a territory of approximately 330 thousand $\mathrm{km}^{2}$. Three climate zones, namely maritime temperate (typical for the mainland), warm summer continental (typical for the eastern-central part) and Mediterranean (typical for the southern part) climate zones, meet in the region. The annual insolation is $4200-4700 \mathrm{MJ} \mathrm{m}^{-2}$, with a maximum in the central part (Spinoni et al., 2014). The annual sunshine duration is between 1850 and $2200 \mathrm{~h}$, which results in an annual relative sunshine duration of $40-47 \%$, with a minimum of $15-20 \%$ in December and a maximum of $55-65 \%$ in August. The annual mean air temperature at the sea level is approximately $10^{\circ} \mathrm{C}$, which is higher by about $2.5^{\circ} \mathrm{C}$ than the global annual mean temperature for corresponding latitudes. There are differences of up to $3-4{ }^{\circ} \mathrm{C}$ in the annual mean temperatures among various subbasins. The mean temperature range is substantial; its annual mean is between 21 and $26^{\circ} \mathrm{C}$ and has a tendency to increase to the $\mathrm{E}$ due to the influence of the continental climate zone. The annual mean rainfall in the lowland is between 600 and $700 \mathrm{~mm}$, with a minimum in the central part of the territory. The Carpathian Basin is located in the belt of the prevailing westerly winds. The bounding mountains, however, represent important barriers to the global wind pattern. The wind directions and speeds within the basin are substantially modified by passing weather systems, inner mountains and local radiation gradients. As a result, the surface westerly winds arriving at the basin are usually spread to $\mathrm{N}$ winds prevailing in the western part and to NW winds occurring especially in the upper central part of the basin. In the southern part of the Great Hungarian Plain, southerly winds often occur, while in the eastern part of the basin, the prevailing wind directions are NE or $\mathrm{N}$ particularly in winter. The annual mean wind speed at the height of $10 \mathrm{~m}$ is between 2 and $4 \mathrm{~m} \mathrm{~s}^{-1}$, with smaller values in autumn and larger values in spring. Weather situations within the basin are generally uniform. For some limited time intervals, rather distinct weather conditions can be realized in the different territories of the basin due to the geographical, meteorological and climate properties and features mentioned above. The land of the basin is mostly used for intensive agriculture and farming, and larger forested areas with deciduous, coniferous or mixed wood oc- cur in the inner and bounding mountains. The total number of inhabitants in the basin is estimated to be 26 million, and its largest city is Budapest with 2.5 million inhabitants in the metropolitan area.

The data evaluated in the present study were obtained in the Budapest and at the K-puszta measurement stations (Fig. 1). The geographical area between the two sites is plain. The measurements in Budapest were carried out continuously in the central part of the city (Lágymányos Campus of the Eötvös University; $47.474^{\circ} \mathrm{N}, 19.062^{\circ} \mathrm{E} ; 114 \mathrm{~m}$ above mean sea level, a.m.s.l.) in an open area near the river Danube from 3 November 2008 to 2 November 2009 (Salma et al., 2011, 2016). The location represents well-mixed urban air in the city centre. Another 1-year-long continuous measurement campaign was realized at the NW border of Budapest in a wooded area (Konkoly Astronomical Observatory of the Hungarian Academy of Sciences; $47.500^{\circ} \mathrm{N}, 18.963^{\circ} \mathrm{E}$; $478 \mathrm{~m}$ a.m.s.l.) from 19 January 2012 to 18 January 2013. This site represents the near-city background. The K-puszta measurement station $\left(46.967^{\circ} \mathrm{N}, 19.586^{\circ} \mathrm{E} ; 127 \mathrm{~m}\right.$ a.m.s.l.) is situated on the Great Hungarian Plain at a distance of $71 \mathrm{~km}$ from and to the SE of Budapest. The station is located in a forest clearing with its near-scale surroundings dominated by mixed forest ( $62 \%$ coniferous, $28 \%$ deciduous) and grassland (10\%). The station represents the rural background. It is involved in the European Monitoring and Evaluation Programme (EMEP station no. HU0002R). Two 1-year-long data sets which correspond exactly to those considered for Budapest were selected for the evaluations.

\subsection{Measurements}

The principal measuring system was a flow-switching type differential mobility particle sizer (DMPS) at both sites. Its main components are a radioactive bipolar charger, a Nafion semipermeable membrane dryer, a differential mobility analyser and a butanol-based condensation particle counter (TSI CPC3775 in Budapest and CPC3772 at the K-puszta station; Aalto et al., 2001). Particles with an electrical mobility diameter from 6 to $1000 \mathrm{~nm}$ (Budapest) and from 6 to $800 \mathrm{~nm}$ (K-puszta, for most of the time) are recorded in their dry state in 30 channels. The sample flow was $2.0 \mathrm{~L} \mathrm{~min}^{-1}$ (Budapest) or $1.0 \mathrm{~L} \mathrm{~min}^{-1}$ (K-puszta) in the high-flow mode and $0.3 \mathrm{~L} \mathrm{~min}^{-1}$ in the low-flow mode. The time resolution of the measurement was approximately $10 \mathrm{~min}$. There was no upper size cut-off inlet applied to the sampling lines, so that only a weather shield and insect net were attached. The DMPS measurements were performed according to the international technical standard (Wiedensohler et al., 2012). Synoptic meteorological data were obtained from regular measurement stations of the Hungarian Meteorological Service operated in Budapest (no. 12843) and at the military airport in Kecskemét (no. 12970). Standardized meteorological measurements of air temperature $(T)$, relative humidity (RH), wind speed (WS), wind direction (WD) and cloudi- 


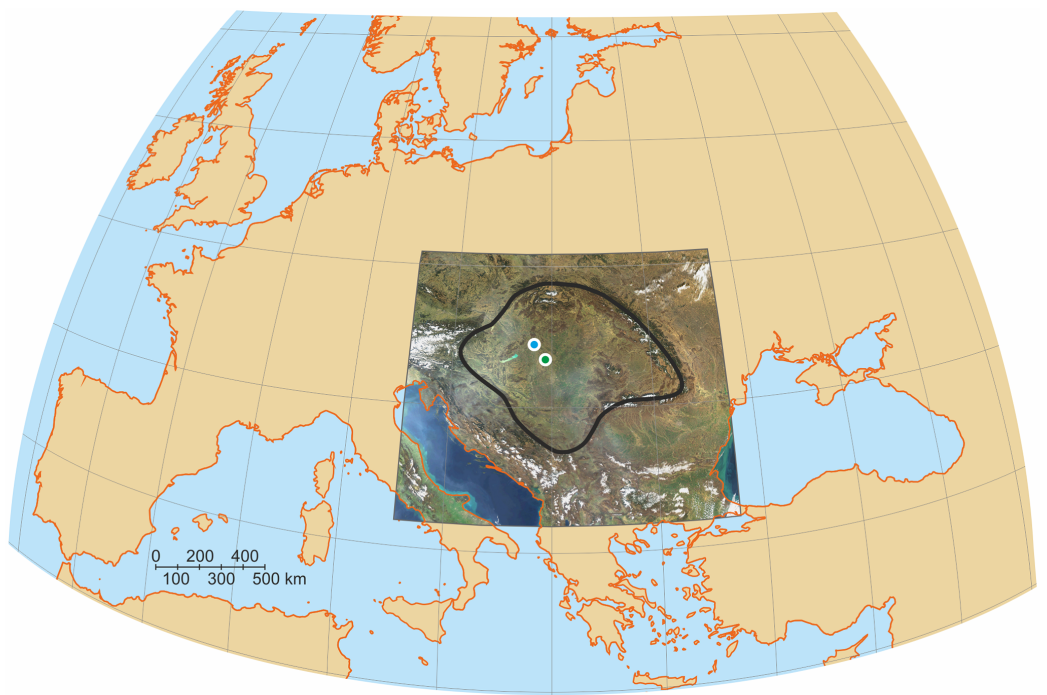

Figure 1. Image of the Carpathian Basin in central Europe retrieved from Aqua/MODIS data indicating the location and advantages of a well-separated basin (marked by black curve) and of the measurement sites in Budapest and at the K-puszta station (shown by blue and green dots, respectively).

ness $(n)$ are recorded at these stations with a time resolution of $1 \mathrm{~h}$. Global radiation (GRad) was calculated from the measured meteorological data using the method of Holtslag and Van Ulden (Foken, 2006; Weidinger et al., 2008). The planetary boundary layer (PBL) height was obtained from the ECMWF Integral Forecast System based on the ERAInterim reanalysis, with a spatial resolution of $0.5^{\circ} \times 0.5^{\circ}$ and a time resolution of $3 \mathrm{~h}$ (Dee et al., 2011). Concentrations of atmospheric criteria pollutants were obtained from the closest measurement station of the National Air Quality Network in Budapest (at a distance of $1.6 \mathrm{~km}$ from the urban site and of $6.9 \mathrm{~km}$ from the near-city background site) and in Százhalombatta (at a distance of $63 \mathrm{~km}$ ) for the Kpuszta station; all are located in the prevailing upwind direction from the measurement sites. The concentration of $\mathrm{SO}_{2}$ in Budapest is ordinary distributed without larger spatial differences (Salma et al., 2016). Ozone and $\mathrm{PM}_{10}$ mass were recorded directly at the K-puszta station. Standardized measurements of $\mathrm{SO}_{2}$ (by UV fluorescence, Ysselbach 43C), $\mathrm{PM}_{10}$ mass (by beta-ray absorption, Thermo FH62-I-R) and $\mathrm{O}_{3}$ (by UV absorption, Ysselbach 49C) with a time resolution of $1 \mathrm{~h}$ are performed at the stations. The DMPS data in Budapest and at the K-puszta station were available for more than 90 and $70 \%$, respectively, of the total number of days, while the coverage of the meteorological and pollutant data were $>80 \%$.

\subsection{Evaluation}

The overall treatment of the measured DMPS data was performed according to the procedure protocol recommended by Kulmala et al. (2012). The individual size distributions were fitted by lognormal functions using the DoFit algorithm
(Hussein et al., 2004). The identification of an NPF and subsequent particle growth process was accomplished by using the algorithm of Dal Maso et al. (2005). The growth rate (GR) of particles in the size interval of 6-25 nm was determined by a lognormal distribution function method (Kulmala et al., 2012). The formation rate $\left(J_{d}\right)$ of particles with a diameter $d$ and condensation sink (CS) were computed according to Kulmala et al. (2012) and Dal Maso et al. (2002), respectively. It is worth mentioning that $J_{d}$ depends implicitly on GR. The earliest estimated time of the beginning of nucleation $\left(t_{1}\right)$, the latest estimated time of the beginning of nucleation $\left(t_{2}\right)$ and the ending time of the particle growth process $\left(t_{e}\right)$ were derived by a comparative method (Németh and Salma, 2014). The time $t_{1}$ also includes the time shift that accounts for the particle growth from the stable neutral cluster mode at $1.5 \pm 0.4 \mathrm{~nm}$ (Kulmala et al., 2007) to the smallest detectable diameter limit of the DMPS systems by adopting the GR value in the size window nearest to it in size space. This approximation can result in an underestimation of the shift by up to $30 \%$ because GR tends to increase with an increasing $d$ in this size range (Kulmala et al., 2012). It is noted that the shifts were mostly smaller than 30-40 min, which seems acceptable with respect to the uncertainty of the starting time parameter $t_{1}$ and to the ordinary dynamics of atmospheric processes. The gas-phase $\mathrm{H}_{2} \mathrm{SO}_{4}$ proxy value was derived as $\left[\mathrm{SO}_{2}\right] \times \mathrm{GRad} / \mathrm{CS}$ for intensities $>10 \mathrm{~W} \mathrm{~m}^{-2}$, and the scaling factor $k$ between the proxy value and $\mathrm{H}_{2} \mathrm{SO}_{4}$ concentration was estimated by an empirical relationship of $k=1.4 \times 10^{-7} \times \mathrm{GRad}^{-0.70}$, where GRad has a unit of $\mathrm{W} \mathrm{m}^{-2}$ (Petäjä et al., 2009). Average proxy values were expressed as absolute concentrations, while the variations in the proxy in figures were shown without adopting the scal- 
ing factor. The scaling factor $k$ was derived specifically for a remote boreal site, and since urban areas are expected to differ from remote regions in this respect (Mikkonen et al., 2011), the diurnal cycling of GRad involved implicitly in the scaling factor could interfere or distort the relationships and trends shown in the figures.

Retrospective movement of the air masses was assessed by backward trajectories, which were generated by using the air parcel trajectory model HYSPLIT v4.9 with an option of vertical velocity mode (Draxler and Rolph, 2013). An embedded Global Data Assimilation System meteorological database was utilized for the modelling, which yields the calculated results on a $1^{\circ}$ latitude-longitude grid. Trajectories arriving at the receptor sites at a height of 200,500 and $2300 \mathrm{~m}$ above the ground level were calculated. For the NPF event days, the start time of the backward modelling was set to the ending time of the particle growth $\left(t_{e}\right)$, and the end time of the computer run was fixed at the earliest beginning of the nucleation $\left(t_{1}\right)$. For the non-event days, the end and start times of the modelling were set to 13:00 and 01:00 UTC +1 , respectively.

A correlation analysis between the joint 2-year-long data sets for Budapest and the K-puszta station was performed on a daily basis. The index of occurrence of 1 was assigned to NPF event days, 0 to undefined and missing days, and -1 to non-event days. The Pearson correlation coefficient and its transformed $t$ value was calculated as

$t=r \sqrt{\frac{n-2}{1-r^{2}}}$

for $n=731$ items and assuming Student's $t$ distribution with $n-2$ degree of freedom.

Wind speed data measured at a height of $10 \mathrm{~m}$ above the ground were recalculated to a height of $200 \mathrm{~m}$ by using the power law approach with an exponent of 0.2 (Irwin, 1967). These WS data were averaged for the area between Budapest and the K-puszta station considering different time intervals. The following four cases were considered: NPF events identified at both measurement sites (BpY\&KpY); an event in Budapest and no event at the K-puszta station $(\mathrm{BpY} \& \mathrm{KpN})$; no event in Budapest and an event at the K-puszta station $(\mathrm{BpN} \& \mathrm{KpY})$; and no event in either the Budapest or $\mathrm{K}$ puszta station (BpN\&KpN). For the case BpY\&KpY, the WS data for the site with the earlier NPF event were selected from the time $t_{1}-1 \mathrm{~h}$ of the earlier site to the time $t_{1}$ of the site with the delayed NPF event, while the WS data for the site with the delayed event were selected from the time $t_{1}$ of the earlier site to the time $t_{1}+1 \mathrm{~h}$ of the delayed site. Finally, the two selected data sets were averaged to a synoptic WS value. For the cases $\mathrm{BpY} \& \mathrm{KpN}$ and $\mathrm{BpN} \& \mathrm{KpY}$, the mean WS value was obtained by averaging the two WS data sets between the times $t_{1}$ and $t_{e}$. For the case $\mathrm{BpN} \& \mathrm{KpN}$, the mean WS value was derived by averaging jointly both WS data sets from the mean time $t_{1}$ to the mean time $t_{e}$. These selections represent sensible and representative approximations to reality. As the next step, comparison of the delay time with the travel time of the synoptic wind was expressed by

$\tau=\frac{\Delta t_{1}}{D} \mathrm{WS}$,

where $D=71 \mathrm{~km}$ is the distance between the centre of $\mathrm{Bu}$ dapest and the K-puszta station. If the ratio $\tau \rightarrow 1$, the nucleating air mass may have transported by advection from the upwind site to the downwind site. If $\tau$ is substantially smaller than 1, the NPF event at the downwind site could not have been transferred by advection from the upwind site but rather formed somewhere else. In our data, $\tau>1$ was caused by large $\left(>7 \mathrm{~m} \mathrm{~s}^{-1}\right) \mathrm{WSs}$, and this took place in a very limited number case, so further investigations (e.g. on the origin of these air masses) require longer data sets.

\section{Results and discussion}

\subsection{Similarities in NPF occurrence}

The annual mean frequencies of NPF events were substantial at our measurement sites compared with most other sites reported in scientific literature (Table 1; Kulmala et al., 2004, and references therein; Dal Maso et al., 2005; Manninen et al., 2010; Borsós et al., 2012; Dall'Osto et al., 2013). This indicates that the typical meteorological and chemical conditions (e.g. higher annual mean $T$ inside the basin, presence of forested areas and availability of $\mathrm{SO}_{2}$ precursor) within the Carpathian Basin favour the occurrence of NPF. The seasonal variability of the NPF frequency was very similar at both sites with a minimum in winter and two local maxima, one in spring and the other in autumn (Fig. 2). The spring maximum took place in April during the first year and in March during the second year. Such a shift can be caused by interannual differences in meteorological conditions (Dal Maso et al., 2005; Hamed et al., 2010) or biogenic cycling through emissions of volatile organic compounds (VOCs) from vegetation (Riipinen et al., 2011; Riccobono et al., 2014). The two measurement sites respond identically to these influences.

In order to investigate more thoroughly whether and how the occurrence of NPF was connected between the two measurement sites, and over the whole basin, we made a statistical analysis and investigated air mass transport effects. For the occurrence of NPF, the joint 2-year-long data set resulted in a correlation coefficient of 0.429 , with a Student's $t$ value of 12.829. The critical Student's $t$ value at a statistical confidence level of $99.99 \%$ is 3.912 , which means that there was a significant linear relationship in the occurrence of the NPF between the two sites. In most cases, the particle growth associated with NPF (the presence of a banana-shaped curve) could be traced for $8-13 \mathrm{~h}$, during which time the air parcel containing nucleated particles travelled a distance comparable to the dimensions of the basin. This result is consistent with other modelling studies on the spatial extent of NPF 


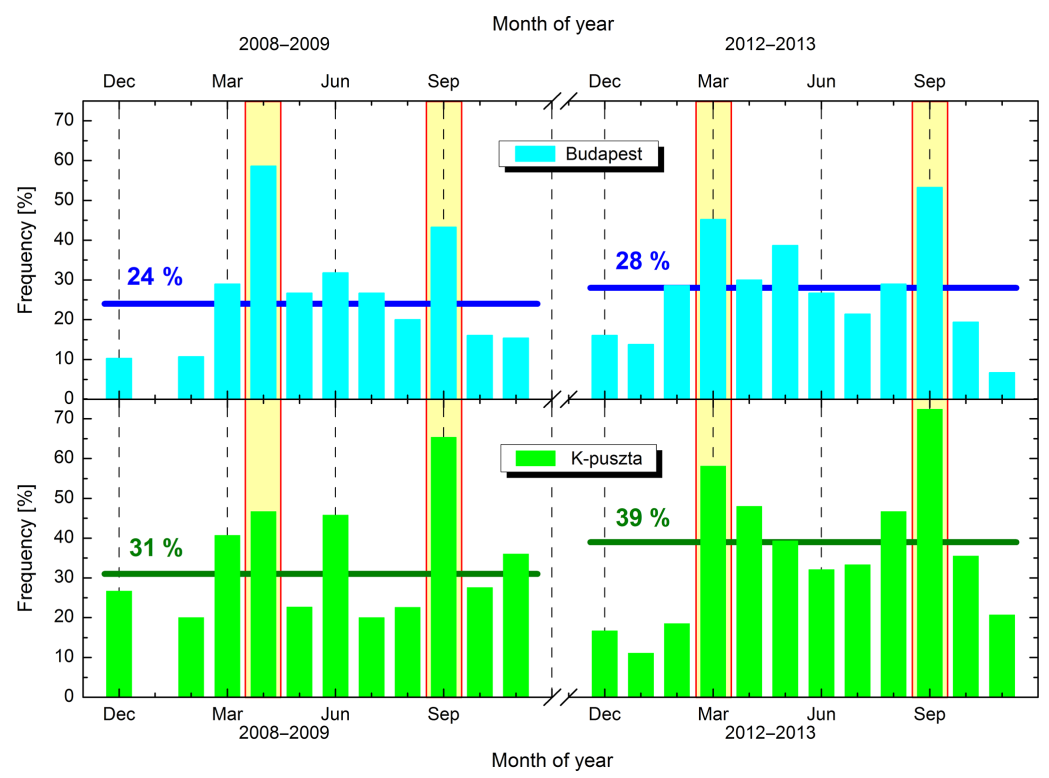

Figure 2. Distribution of monthly mean NPF frequency in Budapest and at the K-puszta station. Annual mean frequencies are indicated by horizontal lines and figures. The spring and autumn maxima are highlighted in yellow bands.

Table 1. Number of days with obvious NPF event, unambiguously no NPF event, undefined days and missing days in Budapest and at the K-puszta station for two 1-year-long time intervals in 2008 2009 and 2012-2013.

\begin{tabular}{lrr}
\hline Time interval/class & Budapest & K-puszta \\
\hline 2008-2009 (365 days) & & \\
\hline Events & 83 & 100 \\
Non-events & 229 & 146 \\
Undefined & 34 & 78 \\
Missing & 19 & 41 \\
\hline 2012-2013 (366 days) & & \\
\hline Events & 96 & 125 \\
Non-events & 231 & 180 \\
Undefined & 19 & 40 \\
Missing & 20 & 21 \\
\hline
\end{tabular}

(Crippa and Pryor, 2013; Németh and Salma, 2014; Pietikäinen et al., 2014).

\subsection{Incidence of NPF events}

The geographical straight line between the two measurement locations is identical with the prevailing wind direction (NW) in the area, which makes it possible to compare the exact timing of the NPF processes at these sites to the air mass advection between the sites (Table 2). Air mass backward trajectories derived for all days were grouped into the following cases: trajectories that ran parallel to the geographical connecting line and arrived from the NW, trajectories parallel to the connecting line and arriving from the SE, trajectories in largely perpendicular directions to the connecting line, and trajectories in unclassified directions. Days with quantifiable NPF event and non-event days in the 2-year-long data set were considered in this evaluation. For simultaneous event days (BpY\&KpY), the NPF events in Budapest occurred later than at the K-puszta station in $75 \%$ of the relevant days, with a mean delay time of $1 \mathrm{~h} 54 \mathrm{~min}$. There were 4 days when the NPF events in Budapest happened earlier than at the K-puszta station, but their mean delay time involved a relative uncertainty of $>80 \%$. For the parallel direction from SE, the NPF events in Budapest occurred later than at the K-puszta station in $85 \%$ of the relevant days with a mean delay time of $1 \mathrm{~h} 11 \mathrm{~min}$. The opposite timing (on 3 days only) yielded a mean delay time with a rather high uncertainty. For the parallel direction from NW, the NPF events in Budapest occurred later than at the K-puszta station on $33 \%$ of the relevant days, with a mean delay time of $1 \mathrm{~h}$. During the days when NPF was taking place at both sites (about $10 \%$ of the days), the mean and standard deviation of the ratio $\tau$ (Eq. 2) were $0.34 \pm 0.25$. This indicates that the air masses only reached approximately one third of the geographical distance when the NPF had already started at the downwind site. Hence, the NPF observed at the downwind site was not because of air mass advection from the upwind site but rather took place simultaneously over large distances in the basin. At the present level of our knowledge, advection of nucleating air masses cannot be excluded in a few cases.

The cumulative results outlined in Sects. 3.1 and 3.2 show that the NPF events observed in the city and its rural background appear in a consistent and spatially coherent way. We 
Table 2. Number and relative frequency of air mass trajectories arriving at the Budapest and K-puszta station in a parallel direction from NW and $\mathrm{SE}$, in perpendicular directions, and in unclassified (other) directions relative to the Budapest-K-puszta station geographical connecting line when there were NPF events identified at both sites (BpY\&KpY), an event in Budapest and no event at the K-puszta station (BpY\&KpN), no event in Budapest and an event at the K-puszta station (BpN\&KpY), and no event at either of the sites (BpN\&KpN).

\begin{tabular}{|c|c|c|c|c|c|c|c|c|}
\hline \multirow{2}{*}{$\begin{array}{l}\text { Trajectory } \\
\text { direction }\end{array}$} & \multicolumn{2}{|c|}{ BpY\&KpY } & \multicolumn{2}{|c|}{ BpY\&KpN } & \multicolumn{2}{|c|}{$\mathrm{BpN} \& \mathrm{KpY}$} & \multicolumn{2}{|c|}{ BpN\&KpN } \\
\hline & No. & $\%$ & No. & $\%$ & No. & $\%$ & No. & $\%$ \\
\hline Parallel from NW & 23 & 36 & 5 & 33 & 9 & 16 & 91 & 34 \\
\hline Parallel from SE & 20 & 31 & 2 & 13 & 28 & 48 & 39 & 14 \\
\hline Perpendicular & 16 & 25 & 8 & 54 & 21 & 36 & 136 & 50 \\
\hline Other & 5 & 8 & 0 & 0.0 & 0 & 0.0 & 4 & 2 \\
\hline All & 64 & 100 & 15 & 100 & 58 & 100 & 270 & 100 \\
\hline
\end{tabular}

interpret this as the result of a common atmospheric nucleation phenomenon in the region with some urban influence.

\subsection{Site-to-site differences in NPF properties}

There were, however, clear differences in the NPF process between the city and rural background. The annual mean NPF occurrence frequencies of 24 and $28 \%$ at the Budapest sites were smaller by factors of 1.3 and 1.4 , respectively, than at the K-puszta station (Fig. 2). Moreover, a continuous suppressing tendency from the rural background through the near-city background to the city centre was found. The mean values of $J_{6}$ and GR for central Budapest exceeded that for the K-puszta station by a factor of 2 and 1.6, respectively, when considering the whole measurement data set (Table 3). This is consistent with the idea that particles capable of escaping coagulation scavenging grow faster in polluted air compared to cleaner environments. Large values of GR are typical for polluted urban atmospheres, such as New Delhi $\left(\mathrm{GR}=11.6-167 \mathrm{~nm} \mathrm{~h}^{-1}\right.$; Kulmala et al., 2005), Mexico City (15-40 $\mathrm{nm} \mathrm{h}^{-1}$; Iida et al., 2008), South Africa (3-21 $\mathrm{nm} \mathrm{h}^{-1}$; Laakso et al., 2008) or Shanghai $\left(11.4 \pm 9.7 \mathrm{~nm} \mathrm{~h}^{-1}\right.$; Xiao et al., 2015). QuantifiableNPF events at the K-puszta station started from 05:35 (on 28 April 2009) to 12:46 (on 15 June 2009). The starting times in the near-city background and city centre of Budapest ranged from 06:55 (on 25 August 2012) to 12:24 (on 11 October 2012) and from 06:11 (on 28 April 2009) to 11:43 (on 9 May 2009), respectively.

The relationship between the major source and sink for gas-phase $\mathrm{H}_{2} \mathrm{SO}_{4}$ for the event days and non-event days is shown in Fig. 3 separately for Budapest and K-puszta. The data for nucleation days are means averaged from the time $t_{1}$ to time $t_{2}$ of an NPF event. The data for non-event days are means derived by averaging between the overall mean times $t_{1}$ and $t_{2}$. All time data were expressed in UTC +1 . Figure 3 suggests that the CS effectively suppresses NPF at values larger than about $20 \times 10^{-3} \mathrm{~s}^{-1}$ at both sites. The common limiting CS value is likely related to some environmental features in the Carpathian Basin. At smaller CS values, a large
Table 3. Mean $J_{6}$, GR and starting time parameter $t_{1}$ with standard deviations for quantifiable regional NPF events in Budapest and at the K-puszta station separately for two 1-year-long time intervals in 2008-2009 and 2012-2013. Numbers of days with quantifiable NPF events are also shown. The measurements in Budapest were performed in the city centre in 2008-2009, while they were carried out in the near-city background in 2012-2013.

\begin{tabular}{lrr}
\hline Time interval/property & Budapest & K-puszta \\
\hline $2008-2009$ (365 days) & & \\
\hline No. of quantifiable events & 31 & 45 \\
$J_{6}\left(\mathrm{~cm}^{-3} \mathrm{~s}^{-1}\right)$ & $4.2 \pm 2.5$ & $1.9 \pm 1.5$ \\
GR $\left(\mathrm{nm} \mathrm{h}^{-1}\right)$ & $7.7 \pm 2.4$ & $4.8 \pm 2.3$ \\
$t_{1}\left(\mathrm{hh}: \mathrm{mm}^{-}\right.$UTC +1$)$ & $09: 25 \pm 01: 11$ & $08: 48 \pm 01: 33$ \\
\hline 2012-2013 (366 days) & & \\
\hline No. of quantifiable events & 43 & 55 \\
$J_{6}\left(\mathrm{~cm}^{-3} \mathrm{~s}^{-1}\right)$ & $2.1 \pm 1.5$ & $1.8 \pm 1.4$ \\
GR $\left(\mathrm{nm} \mathrm{h}^{-1}\right)$ & $5.1 \pm 1.5$ & $4.2 \pm 2.1$ \\
$t_{1}\left(\mathrm{hh:mm}^{-}\right.$UTC +1$)$ & $08: 44 \pm 01: 10$ & $08: 31 \pm 01: 27$ \\
\hline
\end{tabular}

number of non-event days is located above the dividing line in Fig. 3, which can be explained by factors other than CS being active in suppressing the NPF. These include high concentrations of inhibiting chemical species (Kiendler-Scharr et al., 2009), low concentrations of stabilizing compounds such as oxidized VOCs (Riccobono et al., 2014), $\mathrm{NH}_{3}$ and amines (Almeida et al., 2013), or large RH (Hamed et al., 2011). The much lower fraction of event days located below the same dividing line supports the principal role of $\mathrm{H}_{2} \mathrm{SO}_{4}$ in the NPF process (Sipilä et al., 2010), especially for Budapest. The median values of the $\mathrm{H}_{2} \mathrm{SO}_{4}$ proxy concentration for the event days in Budapest $\left(4.8 \times 10^{6}\right.$ molecules $\left.\mathrm{cm}^{-3}\right)$ and $\mathrm{K}$ puszta $\left(4.7 \times 10^{6}\right.$ molecules $\left.\mathrm{cm}^{-3}\right)$ were larger by factors of 1.4 and 1.2, respectively, than for the non-event days at these two sites (Table 4). The mean diurnal variation of the $\mathrm{H}_{2} \mathrm{SO}_{4}$ proxy was also very different between the event and nonevent days, as well as between the two sites (Fig. 4). At the 
Table 4. Medians of gas-phase $\mathrm{H}_{2} \mathrm{SO}_{4}$ concentration, condensation sink (CS), $\mathrm{SO}_{2}$ concentration, global radiation (GRad), relative humidity $(\mathrm{RH})$, air temperature $(T)$, wind speed (WS), cloudiness $(n)$, planetary boundary layer (PBL) height, $\mathrm{O}_{3}$ concentrations on the actual day and

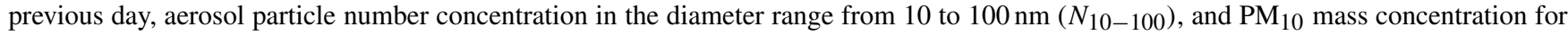
the time interval when NPF events were identified in both Budapest and at the K-puszta station (BpY\&KpY) and when there was an event in Budapest and no event at the K-puszta station $(\mathrm{BpY} \& \mathrm{KpN})$, no event in Budapest and an event at the K-puszta station (BpN\&KpY), and no event in both Budapest and at the K-puszta station (BpN\&KpN).

\begin{tabular}{|c|c|c|c|c|c|c|c|c|}
\hline \multirow[t]{2}{*}{ Variable } & \multicolumn{2}{|c|}{ BpY\&KpY } & \multicolumn{2}{|c|}{ BpY\&KpN } & \multicolumn{2}{|c|}{ BpN\&KpY } & \multicolumn{2}{|c|}{$\mathrm{BpN \& KpN}$} \\
\hline & Budapest & K-puszta & Budapest & K-puszta & Budapest & K-puszta & Budapest & K-puszta \\
\hline$\left[\mathrm{H}_{2} \mathrm{SO}_{4}\right] \times 10^{-6}\left(\right.$ molecules $\left.\mathrm{cm}^{-3}\right)$ & 5.1 & 5.4 & 4.4 & 4.3 & 3.4 & 4.0 & 3.3 & 3.5 \\
\hline $\mathrm{CS} \times 10^{3}\left(\mathrm{~s}^{-1}\right)$ & 7.9 & 6.6 & 8.8 & 6.8 & 14.6 & 8.1 & 11.9 & 9.6 \\
\hline $\mathrm{SO}_{2}\left(\mu \mathrm{g} \mathrm{m}^{-3}\right)$ & 7.1 & 6.2 & 6.9 & 5.3 & 7.6 & 6.9 & 7.2 & 6.1 \\
\hline $\operatorname{GRad}\left(\mathrm{W} \mathrm{m}^{-2}\right)$ & 310 & 276 & 338 & 346 & 225 & 240 & 113 & 122 \\
\hline $\mathrm{RH}(\%)$ & 40 & 45 & 41 & 44 & 54 & 61 & 70 & 78 \\
\hline$T\left({ }^{\circ} \mathrm{C}\right)$ & 18.2 & 17.4 & 22 & 24 & 16.0 & 15.6 & 7.7 & 8.0 \\
\hline $\mathrm{WS}\left(\mathrm{m} \mathrm{s}^{-1}\right)$ & 2.6 & 3.5 & 2.2 & 2.9 & 2.2 & 3.7 & 2.1 & 3.0 \\
\hline$n$ (okta) & 2.6 & 2.5 & 4.4 & 4.8 & 5.6 & 5.3 & 6.4 & 6.3 \\
\hline PBL (km) & 0.96 & 0.95 & 1.31 & 1.31 & 0.78 & 0.81 & 0.57 & 0.53 \\
\hline $\mathrm{O}_{3}\left(\mu \mathrm{g} \mathrm{m}^{-3}\right)$ & 76 & 83 & 93 & 96 & 61 & 75 & 46 & 52 \\
\hline $\mathrm{O}_{3}$ for prev. day $\left(\mu \mathrm{g} \mathrm{m}^{-3}\right)$ & n.r. & 76 & n.r. & 62 & n.r. & 75 & n.r. & 49 \\
\hline$N_{10-100} \times 10^{-3}\left(\mathrm{~cm}^{-3}\right)$ & 8.5 & 8.3 & 8.2 & 2.6 & 6.5 & 7.3 & 4.1 & 2.6 \\
\hline $\mathrm{PM}_{10}$ mass $\left(\mu \mathrm{g} \mathrm{m}^{-3}\right)$ & 21 & 21 & 20 & 16.9 & 26 & 22 & 28 & 23 \\
\hline
\end{tabular}

n.r.: not relevant

mean NPF starting time for Budapest of $t_{1}=09: 25 \mathrm{UTC}+1$, the $\mathrm{H}_{2} \mathrm{SO}_{4}$ proxy appears to be separated into larger values $\left(>45 \times 10^{4} \mathrm{\mu g} \mathrm{m}^{-5} \mathrm{~W} \mathrm{~s} \propto 6 \times 10^{6}\right.$ molecules $\left.\mathrm{cm}^{-3}\right)$ for event days and smaller values $\left(<25 \times 10^{4} \mu \mathrm{g} \mathrm{m}^{-5} \mathrm{~W} \mathrm{~s} \propto 3 \times\right.$ $10^{6}$ molecules $\mathrm{cm}^{-3}$ ) for non-event days. This partitioning is related to the availability of $\mathrm{H}_{2} \mathrm{SO}_{4}$ and seems to explain the observed variability in the occurrence of NPF in Budapest. In contrast, the $\mathrm{H}_{2} \mathrm{SO}_{4}$ proxy for the K-puszta station at the mean NPF starting time of $t_{1}=08: 40 \mathrm{UTC}+1$ lies in a narrow band, except for the case BpY\&KpY. The $\mathrm{H}_{2} \mathrm{SO}_{4}$ proxy utilized in the present study only takes the main atmospheric oxidation of $\mathrm{SO}_{2}$ by the $\mathrm{OH}$ radical into account. Recent field observations supported by laboratory experiments and theoretical considerations point to capacities of stabilized Criegee intermediates (sCIs) in forests to oxidize $\mathrm{SO}_{2}$ into $\mathrm{H}_{2} \mathrm{SO}_{4}$, with a contribution of up to 33-46\% of $\mathrm{H}_{2} \mathrm{SO}_{4}$ concentration at ground level (Mauldin III et al., 2012; Boy et al., 2013). SCIs are formed by ozonolysis of unsaturated organics, including terpenoid compounds which are emitted in large amounts by plants. Thus, a biogenically related mechanism cannot be excluded for the NPF events observed just after the sunrise at the $\mathrm{K}$-puszta station.

Based on the $\mathrm{H}_{2} \mathrm{SO}_{4}$ proxy concentration, the mean contribution of $\mathrm{H}_{2} \mathrm{SO}_{4}$ condensation to the particle GR was estimated to be 12.3 and $11.8 \%$ for Budapest and K-puszta, respectively. This indicates that other chemical species, presumably organic compounds, have a large influence on the growth of newly formed particles in the basin and possibly also on the NPF process itself. The increase in the GR with an increasing particle size reported earlier for the K-puszta station (Yli-Juuti et al., 2009) is strongly in line with this view.
Previous studies have identified extremely low-volatility organic compounds (ELVOCs) playing an important role in both the NPF and particle growth. Such compounds were first predicted by Kulmala et al. (1998) and later identified from the oxidation of $\alpha$-pinene and other terpenoids in smog chamber experiments (Ehn et al., 2014; Jokinen et al., 2015). ELVOCs appear to be formed with substantial mass yields under atmospherically relevant conditions and their dimers seem large enough to act as nano-condensation nuclei for their further irreversible growth (Ehn et al., 2014). Our results indicate a clear contribution of compounds other than $\mathrm{H}_{2} \mathrm{SO}_{4}$ in the initial and subsequent growth processes. Since the saturation vapour pressure of those compounds needs to be very low, it is probable that ELVOCs are the main contributors for this in the Carpathian Basin.

\subsection{Spatial variability of NPF occurrence on a subregional scale}

In order to find out the primary causes for the subregional differences, we derived median values of the relevant meteorological data and air pollutant concentrations separately for the following cases: BpY\&KpY, BpY\&KpN, BpN\&KpY and $\mathrm{BpN} \& \mathrm{KpN}$ (Table 4). Since the details of the possible oxidation of $\mathrm{SO}_{2}$ by sCIs are not exactly known, median $\mathrm{O}_{3}$ concentrations for the day before an NPF event were also added for the K-puszta station. The averaging was first performed from time $t_{1}$ to time $t_{e}$. In the case of BpY\&KpY, the actual time parameters for each measurement site were utilized. In the cases of $\mathrm{BpY} \& \mathrm{KpN}$ and $\mathrm{BpN} \& \mathrm{KpY}$, the time parameters of the NPF event for one of the measurement sites 

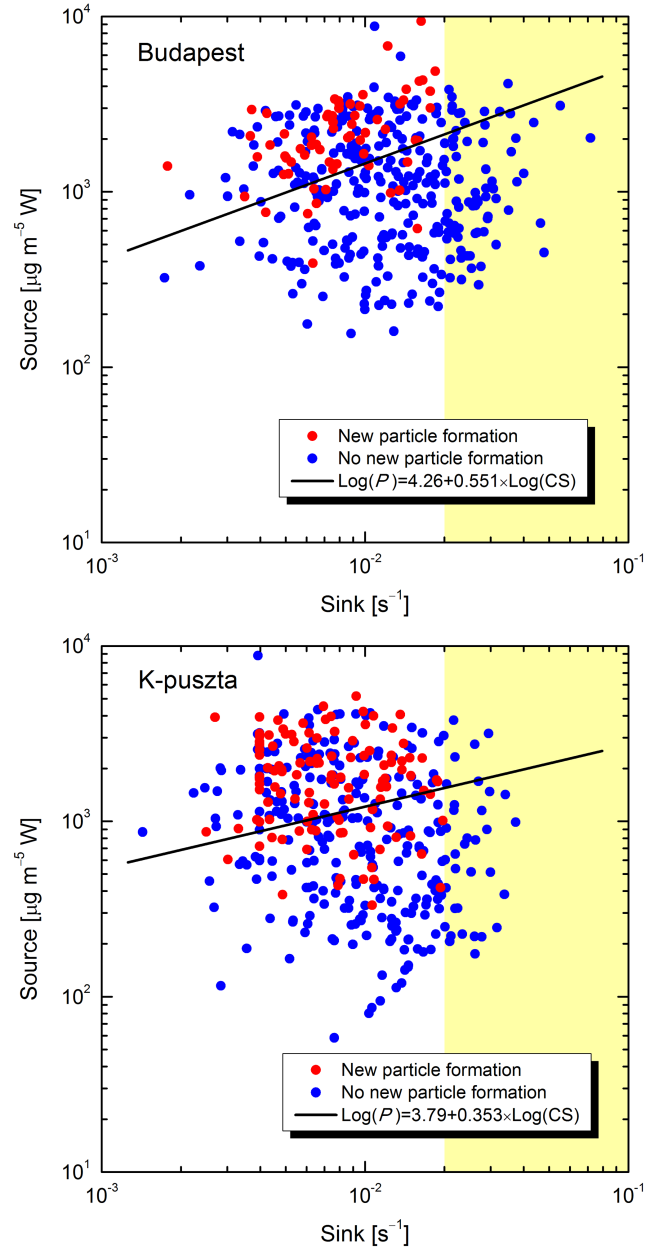

Figure 3. Relationship of the major source and sink of gas-phase $\mathrm{H}_{2} \mathrm{SO}_{4}$. The data are shown separately for the quantifiable-event days and non-event days in Budapest and at the K-puszta station for the whole 2-year-long time interval. Product $P$ of $\mathrm{SO}_{2}$ concentration and global radiation was considered as the major source and CS as the major sink. The yellow areas indicate the CS range in which the NPF events were suppressed over the whole region.

were used for the other, non-event site as well. In the case of $\mathrm{BpN} \& \mathrm{KpN}$, the overall-mean time parameters $t_{1}$ and $t_{e}$ were adopted as averaging limits. For GRad and $\mathrm{H}_{2} \mathrm{SO}_{4}$ concentration, the ending time $t_{e}$ was replaced by time $t_{2}$. These averaging limits represent time intervals in which the NPF event and particle growth are the most pronounced. Finally, the mean values for particular days were further averaged separately for the four combination cases mentioned above. It is worth mentioning that an NPF occurrence depends on a complex set of multiple variables. All of them contain relevant information, while it cannot be expected that any standalone property or paired relationship can explain, or even be directly linked to, the NPF occurrence.
The variability in GRad, RH, $T$ and PBL height are strongly biased by the seasonal cycle of solar radiation via the distribution of the monthly NPF frequency, and, therefore, their tendencies are to be approached with special care. The variables $\mathrm{PM}_{10}$ and WS did not seem to contribute substantially to the explanation of the heterogeneity, while $N_{10-100}$ just reflected the fact that NPF increases the number concentration of pre-existing particles extensively (by a factor of 2-3 for Budapest; Salma et al., 2011). Mean concentrations of $\mathrm{O}_{3}$ were larger at the K-puszta station than in Budapest, and they were also larger on NPF days than on non-event days, which indicates a larger photochemical activity in the former case. Cloudiness showed a weak reciprocal tendency with NPF. The occurrence of NPF events did not seem to be sensitive to the $\mathrm{SO}_{2}$ concentration, which suggests that this precursor gas was available at sufficient quantities for NPF to occur during most of the time. The excess concentrations are realized in spite of the fact that the estimated reduction in $\mathrm{SO}_{2}$ emission between 1990 and 2004 was more than $60 \%$ that in most European countries, including Hungary (Hamed et al., 2010). The condensation sink in Budapest exhibited a general dependency in that NPF events occur preferably on days with low values of CS values, being larger by approximately $50 \%$ during the non-event days compared with the event days. This implies that the CS affected the NPF in the Budapest area and that it can have a preventative influence on the events. In contrast, the mean CS values for K-puszta station showed much less or even little effect. The condensation sink depends sensitively on the concentration and size distribution of pre-existing aerosol particles. At the K-puszta station, the average particle number concentration levels are substantially lower, and, thus, the CS values and their changes are smaller as well.

For the mixed cases of $\mathrm{BpN} \& \mathrm{KpY}$ and $\mathrm{BpY} \& \mathrm{KpN}$, the difference between the two types of data was considered to be significant if they diverged at least by a factor of 2 . For cloudiness, a difference larger than 2 okta at an absolute value larger than 5 okta was required, similarly to $\mathrm{RH}$, for which a difference of $15 \%$ at an absolute values of $>70 \%$ was needed for a significant difference (Boy and Kulmala, 2002). These criteria are in line with the current understanding of the conditions for the NPF process (Hamed et al., 2011) and represent sensible approximations to reality. Of 58 cases of $\mathrm{BpN} \& \mathrm{KpY}$, on 19 days the CS was significantly larger, on 8 days the $\mathrm{H}_{2} \mathrm{SO}_{4}$ proxy was significantly smaller, on 8 days the CS was significantly larger and the proxy was significantly smaller, on 4 days both the absolute value of the RH and its difference between the two sites were large, on 3 days both the absolute value of the cloudiness and its difference between the two sites were large, and on 1 day the proxy was significantly smaller and both the absolute value of the cloudiness and its difference between the two sites were large in Budapest compared with the K-puszta station. These findings explain $77 \%$ of the investigated days. On a further 2 days, some important data were missing, and, 

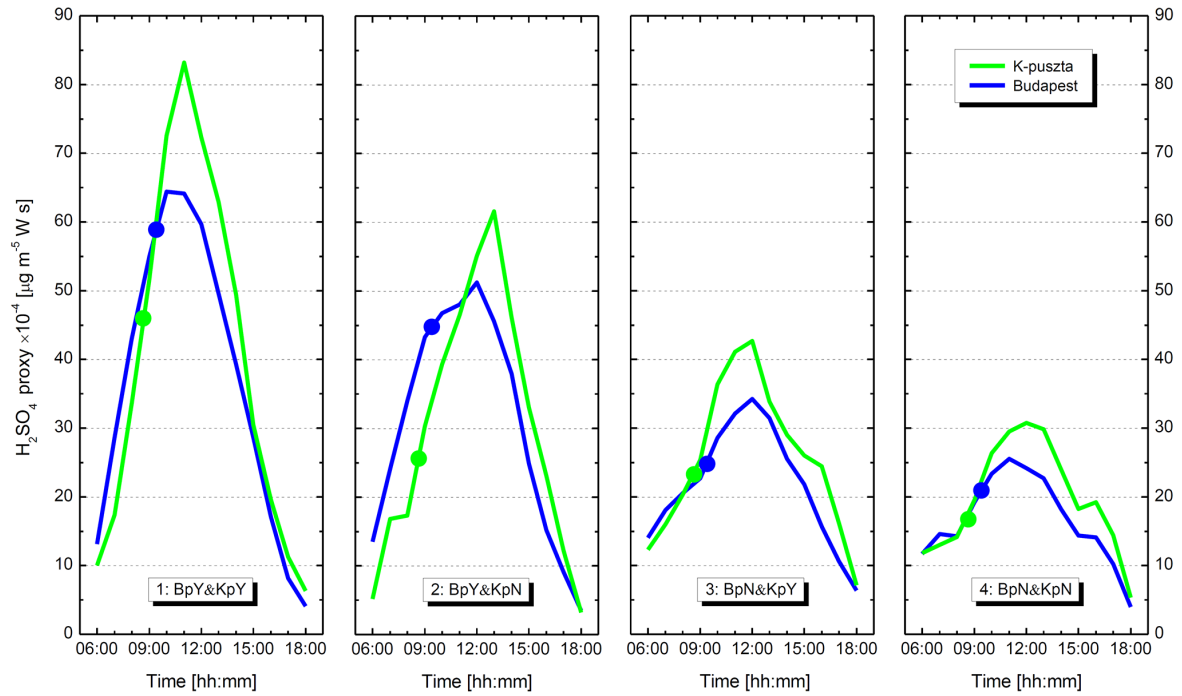

Figure 4. Hourly mean values of gas-phase $\mathrm{H}_{2} \mathrm{SO}_{4}$ proxy in Budapest and at the K-puszta station averaged for the days when NPF events were identified in both Budapest and at the K-puszta station (BpY\&KpY) and when there was an event in Budapest and no event at the $\mathrm{K}$-puszta station $(\mathrm{BpY} \& \mathrm{KpN})$, no event in Budapest and an event at the K-puszta station (BpN\&KpY), and no event in both Budapest and at the K-puszta station $(\mathrm{BpN} \& \mathrm{KpN})$. The proxy values at the mean starting time $t_{1}$ of the NPF are indicated by dots on the curves.

therefore, their evaluation was not possible. In $23 \%$ of the relevant days, we could not prove that there are plausible causes for the spatial difference. About $15 \%$ of these days occurred in summer, late spring or early autumn, when the $\mathrm{O}_{3}$ production and its chemical reactions could be important, and there was an indication of increased $\mathrm{O}_{3}$ concentration overnight before the NPFs. It is hypothesized that most of these unexplained events at the K-puszta station were explicit cases of an sCI oxidation mechanism. For the case BpY\&KpN, 11 days ( $67 \%$ of the days) could be explained by greater cloudiness, $\mathrm{RH}, \mathrm{CS}$ and WS and/or lower $\mathrm{SO}_{2}$ at the K-puszta station compared with Budapest. The number of days with missing data was three. Possible factors for the unexplained days can also include different weather systems at, or weather fronts between, the measurement sites, different air masses, or the conservative selection criteria applied. The area between Budapest and the K-puszta station is inhabited, and the effects of settlements on the atmospheric environment also limit the homogeneity of larger air masses. By analysing the data set, we can conclude that the two major candidates for explaining the differences in the occurrence of $\mathrm{NPF}$ are the higher CS in Budapest and the smaller gas-phase $\mathrm{H}_{2} \mathrm{SO}_{4}$ concentration at K-puszta.

\subsection{Regional- and urban-type NPF events}

We observed NPF and subsequent particle growth events with at least two consecutive onsets on some days, in particular in the near-city background. Of the 43 quantifiable events there, there were $8 \mathrm{NPF}$ events with a double start. A surface plot displaying a typical double start together with the temporal evolution of some related quantities is shown in
Fig. 5 as an example. The quantities related to the NPF events (e.g. $N_{6-25}$ and gas-phase $\mathrm{H}_{2} \mathrm{SO}_{4}$ proxy) varied substantially and rapidly in time, whereas the concentration $N_{100-1000}$, which represents a larger region, stayed stable. This means that there was no extraordinary change in the dynamics of the PBL or weather situation during the time interval of the two onsets. In addition, there was no indication of sudden changes in the local WD, WS and GRad data or in the air mass origin and path during the relevant time intervals. Based on these arguments, an interrupted and renewed (started over) NPF and particle growth process due to the changes in local meteorology or to two different air masses transported to the measurement site can largely be excluded, and there must be other primary reasons for the double starts.

The characteristics of NPF for the event consisting of two onsets were quite different from each other (Table 5). The mean ratio and standard deviation of $J_{6}$ and GR between the two onsets were $2.5 \pm 1.0$ and $1.8 \pm 0.5$, respectively, and the mean difference and standard deviation between the corresponding starting times were $2 \mathrm{~h} 12 \pm 36 \mathrm{~min}$. The individual $J_{6} \mathrm{~s}$ and GRs for the NPF events with a single start and for the two onsets of the NPF events with a double start are shown in Fig. 6. The dynamic properties of the onset 2 (later event) were always larger than those of the corresponding onset 1 (earlier event). In addition, the mean NPF characteristics of the earlier onsets were similar to those of the single-onset events within the uncertainty interval, indicative of their common cause, and also similar to those of the rural background data (Yli-Juuti et al., 2009). At the same time, the mean NPF characteristics of the later onsets were close to those for the city centre data (Salma et al., 2011). This 


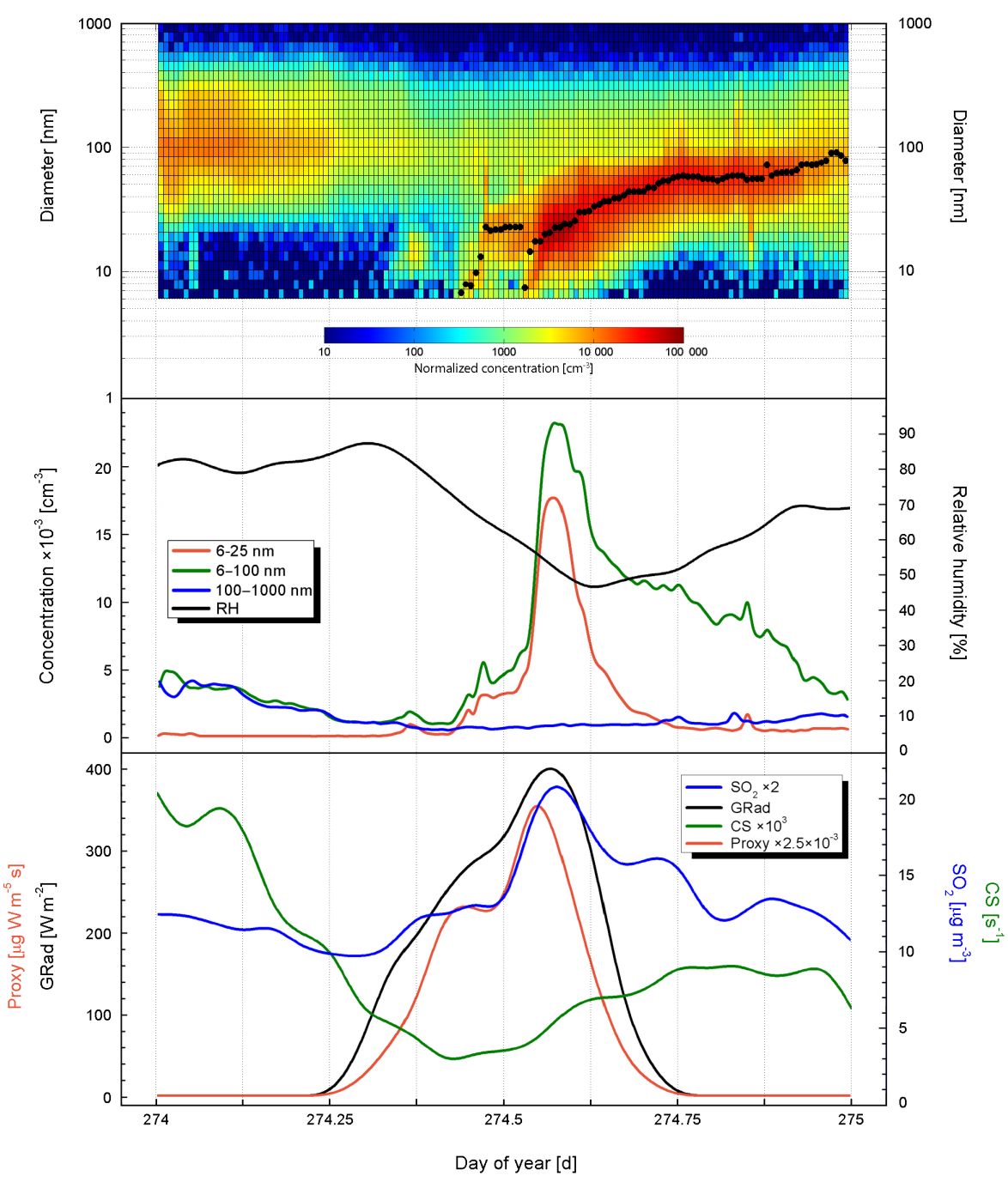

Figure 5. Surface plot (upper panel) for Sunday, 30 September 2012, showing an NPF and growth event with double consecutive start in the near-city background of Budapest. Time series of the fitted particle number median diameter for the nucleation mode are indicated by black dots. For the onsets 1 and 2, the $J_{6} \mathrm{~s}$ were 1.34 and $5.9 \mathrm{~cm}^{-3} \mathrm{~s}^{-1}$, respectively, the GRs were 7.7 and $12.9 \mathrm{~nm} \mathrm{~h}^{-1}$, respectively, and the starting times $t_{1}$ were 09:53 and 12:18 current local time $(\mathrm{UTC}+2)$, respectively. Temporal evolution of particle number concentrations $N_{6-25}$, $N_{6-100}$ and $N_{100-1000}$ and of $\mathrm{RH}$ are displayed in the middle panel. The lower panel shows the diurnal variation of $\mathrm{SO}_{2}$ concentration, GRad, CS and gas-phase $\mathrm{H}_{2} \mathrm{SO}_{4}$ proxy.

suggests that the later events occurred in a more polluted air, which was unambiguously of urban origin.

The interpretation given above is supported by the observations that the later onsets generally happened when the $\mathrm{H}_{2} \mathrm{SO}_{4}$ proxy was high, and they might also be associated with larger $J \mathrm{~s}$, GRs and, more importantly, with larger GRs normalized to the $\mathrm{H}_{2} \mathrm{SO}_{4}$ proxy (Fig. 7). These relationships appear as tendencies, which suggests that the differences between the two onsets are of qualitative character. At the Kpuszta station, there was no NPF observed on 2 of the 8 related days, and for 1 day, some important data were missing, and, therefore, the number of available data points for the K-puszta station is limited. It appears, however, that the overall conditions for the NPF process are met for the whole region. If this is realized, then a regional event likely occurs, which can be accompanied by an urban-type NPF at a later time. This may take place, for instance, by mixing regional and urban air parcels that exhibit different properties, which are mainly governed by local PBL dynamics and urban heat island effects. We relate these distinctions to an urban influence. Our interpretation is supported by a previous observation of NPF event with multiple onsets in semi-clean savannah and industrial environments (Hirsikko et al., 2013), in addition to which it fits very well into the existing ideas on mixing regional and urban air parcels that exhibit different properties such as precursor concentrations, $T$ and $\mathrm{RH}$, and 


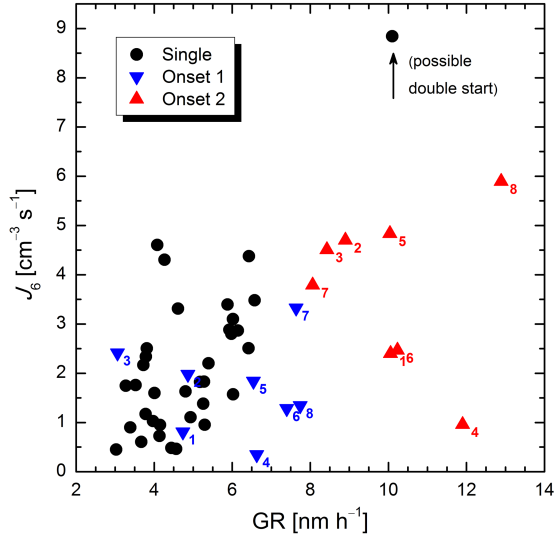

Figure 6. Dynamic properties for the NPF with single start and for the onsets 1 and 2 of the events with double start in the near-city background of Budapest. The data pairs corresponding to the two onsets of an event are indicated by numbers. The data point marked as possible double onset (on 28 April 2012) was assigned to a weak onset 1 and a rather intensive onset 2 by visual inspection although the identification of the two nucleation modes in the size distributions by fitting was not achieved, likely due to the fluctuating data.

Table 5. Range of $J_{6}$, GR and starting time $t_{1}$ in UTC +1 together with their mean values and standard deviations (SDs) calculated jointly for the single events and the onset 1 of the NPF events with double start (regional events) and separately for the onset 2 of the events with double start (urban events) in the near-city background of Budapest.

\begin{tabular}{|c|c|c|c|}
\hline Property & $J_{6}\left(\mathrm{~cm}^{-3} \mathrm{~s}^{-1}\right)$ & $\mathrm{GR}\left(\mathrm{nm} \mathrm{h}^{-1}\right)$ & $t_{1}(\mathrm{hh}: \mathrm{mm})$ \\
\hline \multicolumn{4}{|c|}{ Single + onset 1 (43 days) } \\
\hline Range & $0.35-8.8$ & $3.0-10.7$ & 06:07-12:07 \\
\hline Mean \pm SD & $2.1 \pm 1.5$ & $5.1 \pm 1.5$ & $08: 44 \pm 01: 10$ \\
\hline \multicolumn{4}{|c|}{ Onset 2 ( 8 days) } \\
\hline Range & $0.96-5.9$ & $8.1-12.9$ & 09:05-12:18 \\
\hline Mean \pm SD & $3.7 \pm 1.6$ & $10.1 \pm 1.7$ & $10: 27 \pm 01: 05$ \\
\hline
\end{tabular}

it is mainly governed by local PBL dynamics (Nilsson and Kulmala, 1998).

\section{Conclusions}

The cumulative evidence on urban vs. non-urban similarities and differences in NPF and growth processes suggests that NPF events observed in a well-defined and large enough atmospheric environment (such as the Carpathian Basin) appear in a consistent and spatially coherent way as result of a common atmospheric phenomenon taking place over large horizontal scales. The conclusion does not necessarily mean that NPF events happen uniformly either in time or space within the whole basin, since subtle differences in the spatial concentration gradients, PBL dynamics or local quench-

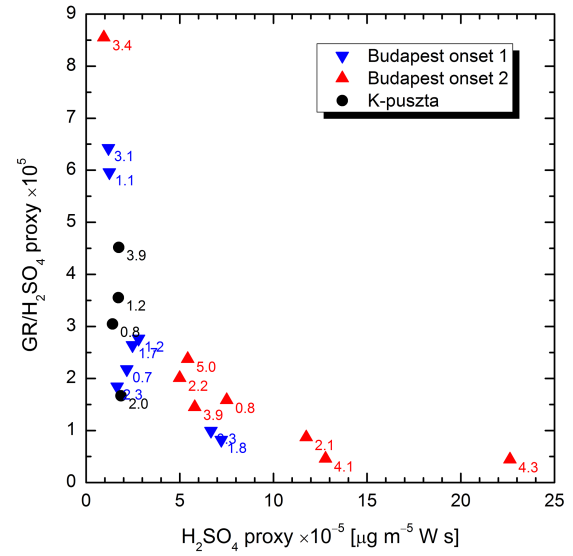

Figure 7. Dependence of the growth rate of NPF for a unity $\mathrm{H}_{2} \mathrm{SO}_{4}$ proxy on the proxy value separately for the onsets 1 and 2 of the events with double start in the near-city background of Budapest and for the regional NPF at the K-puszta station on identical days. The numbers next to the symbols express $J_{6}$ in a unit of $\mathrm{cm}^{-3} \mathrm{~s}^{-1}$.

ing effects for supersaturation over some territories can cause systematic or accidental spatial and temporal variability and alterations. In this way, regional NPF events also interact and, hence, are modified, extended or transformed by urban influences and properties as well. There are strong relationships between cities and their regional environments in that sense, and the joint regional-type and adherent urban-type NPF events can influence the urban climate. Although the particles from NPF and growth events can have physical and chemical properties different from urban ultrafine particles, in general, they may contribute to the excess health risk from nanoparticle exposure of the public (in particular of persons whose health is compromised) in cities. This working hypothesis also opens new potentials and challenges for further health-related studies on ambient aerosol nanoparticles and requires further dedicated research projects.

\section{Data availability}

The observational data used in this paper are available on request from the data owners I. Salma (for Budapest) and M. Kulmala (for the K-puszta station).

Author contributions. Imre Salma and Markku Kulmala designed the study. Zoltán Németh and Pasi Aalto conducted the data collection and treatment. Zoltán Németh, Tuomo Nieminen, Imre Salma, Tamás Weidinger, Ágnes Molnár and Kornélia Imre performed the data analyses and modelling calculations. Imre Salma, VeliMatti Kerminen, Markku Kulmala and Zoltán Németh were involved in the interpretation of the results. Imre Salma and VeliMatti Kerminen wrote the manuscript. Markku Kulmala improved the content of the manuscript. The authors declare no competing financial interests. 
Acknowledgements. The research was financially supported by the Hungarian Scientific Research Fund (no. K116788), ERCAdvanced grant ATMNUCLE (no. 227463) and the Academy of Finland (Center of Excellence project, no. 1118615). The authors thank E. Keszei for the discussions on statistical methods, A. Kern and Zs. Ungvári for the preparation of Fig. 1, and Z. Blumberger (all of the Eötvös University) for his help in air parcel trajectory calculations. The PBL data were obtained courtesy of I. Ihász of the Hungarian Meteorological Service.

Edited by: E. Weingartner

Reviewed by: three anonymous referees

\section{References}

Aalto, P., Hämeri, K., Becker, E., Weber, R., Salm, J., Mäkelä, J. M., Hoell, C., O’Dowd, C. D., Karlsson, H., Hansson, H.-C., Väkevä, M., Koponen, I. K., Buzorius, G., and Kulmala, M.: Physical characterization of aerosol particles during nucleation events, Tellus B, 53, 344-358, 2001.

Alam, A., Shi, J. P., and Harrison, R. M.: Observation of new particle formation in urban air, J. Geophys. Res., 108, 4093-4107, 2003.

Almeida, J., Schobesberger, S., Kurten, A., Ortega, I. K., Kupiainen-Maatta, O., Praplan, A. P., Adamov, A., Amorim, A., Bianchi, F., Breitenlechner, M., David, A., Dommen, J., Donahue, N. M., Downard, A., Dunne, E., Duplissy, J., Ehrhart, S., Flagan, R. C., Franchin, A., Guida, R., Hakala, J., Hansel, A., Heinritzi, M., Henschel, H., Jokinen, T., Junninen, H., Kajos, M., Kangasluoma, J., Keskinen, H., Kupc, A., Kurten, T., Kvashin, A. N., Laaksonen, A., Lehtipalo, K., Leiminger, M., Leppa, J., Loukonen, V., Makhmutov, V., Mathot, S., McGrath, M. J., Nieminen, T., Olenius, T., Onnela, A., Petäjä, T., Riccobono, F., Riipinen, I., Rissanen, M., Rondo, L., Ruuskanen, T., Santos, F. D., Sarnela, N., Schallhart, S., Schnitzhofer, R., Seinfeld, J. H., Simon, M., Sipila, M., Stozhkov, Y., Stratmann, F., Tome, A., Trostl, J., Tsagkogeorgas, G., Vaattovaara, P., Viisanen, Y., Virtanen, A., Vrtala, A., Wagner, P. E., Weingartner, E., Wex, H., Williamson, C., Wimmer, D., Ye, P. L., Yli-Juuti, T., Carslaw, K. S., Kulmala, M., Curtius, J., Baltensperger, U., Worsnop, D. R., Vehkamaki, H., and Kirkby, J.: Molecular understanding of sulphuric acid-amine particle nucleation in the atmosphere, Nature, 502, 359-363, 2013.

Baltensperger, U., Streit, N., Weingartner, E., Nyeki, S., Prévôt, A. S. H., Van Dingenen, R., Virkkula, A., Putaud, J. P., Even, A., Brink, H., Blatter, A., Neftel, A., and Gaggeler, H. W: Urban and rural aerosol characterization of summer smog events during the PIPAPO field campaign in Milan, Italy, J. Geophys. Res., 107, 8193, doi:10.1029/2001JD001292, 2002.

Borsós, T., Řimnáčová, D., Ždímal, V., Smolík, J., Wagner, Z., Weidinger, T., Burkart, J., Steiner, G., Reischl, G., Hitzenberger, R., Schwarz, J., and Salma, I.: Comparison of particulate number concentrations in three Central European capital cities, Sci. Total Environ., 433, 418-426, 2012.

Boy, M. and Kulmala, M.: The part of the solar spectrum with the highest influence on the formation of SOA in the continental boundary layer, Atmos. Chem. Phys., 2, 375-386, doi:10.5194/acp-2-375-2002, 2002.
Boy, M., Mogensen, D., Smolander, S., Zhou, L., Nieminen, T., Paasonen, P., Plass-Dülmer, C., Sipilä, M., Petäjä, T., Mauldin, L., Berresheim, H., and Kulmala, M.: Oxidation of $\mathrm{SO}_{2}$ by stabilized Criegee intermediate (sCI) radicals as a crucial source for atmospheric sulfuric acid concentrations, Atmos. Chem. Phys., 13, 3865-3879, doi:10.5194/acp-13-3865-2013, 2013.

Carslaw, K. S., Lee, L. A., Reddington, C. L., Pringle, K. J., Rap, A., Forster, P. M., Mann, G. W., Spracklen, D. V., Woodhouse, M. T., Regayre, L. A., and Pierce, J. R: Large contribution of natural aerosols to uncertainty in indirect forcing, Nature, 503, 67-71, 2013.

Crippa, P. and Pryor, S. C.: Spatial and temporal scales of new particle formation events in eastern North America, Atmos. Environ., 75, 257-264, 2013.

Dal Maso, M., Kulmala, M., Lehtinen, K. E. J., Mäkelä, J. M., Aalto, P. P., and O'Dowd, C.: Condensation and coagulation sinks and formation of nucleation mode particles in coastal and boreal forest boundary layers, J. Geophys. Res., 107, 8097, doi:10.1029/2001jd001053, 2002.

Dal Maso, M., Kulmala, M., Riipinen, I., Wagner, R., Hussein, T., Aalto, P. P., and Lehtinen, K. E. J.: Formation and growth of fresh atmospheric aerosols: eight years of aerosol size distribution data from SMEAR II, Hyytiälä, Finland, Boreal Environ. Res., 10, 323-336, 2005.

Dall'Osto, M., Querol, X., Alastuey, A., O’Dowd, C., Harrison, R. M., Wenger, J., and Gómez-Moreno, F. J.: On the spatial distribution and evolution of ultrafine particles in Barcelona, Atmos. Chem. Phys., 13, 741-759, doi:10.5194/acp-13-741-2013, 2013.

Dee, D. P., Uppala, S. M., Simmons, A. J., Berrisford, P., Poli, P., Kobayashi, S., Andrae, U., Balmaseda, M. A., Balsamo, G., Bauer, P., Bechtold, P., Beljaars, A. C. M., van de Berg, L., Bidlot, J., Bormann, N., Delsol, C., Dragani, R., Fuentes, M., Geer, A. J., Haimberger, L., Healy, S. B., Hersbach, H., Hólm, E. V., Isaksen, L., Kållberg, P., Köhler, M., Matricardi, M., McNally, A. P., Monge-Sanz, B. M., Morcrette, J.-J., Park, B.-K., Peubey, C., de Rosnay, P., Tavolato, C., Thépaut, J.-N., and Vitart, F.: The ERA-Interim reanalysis: configuration and performance of the data assimilation system, Q. J. Roy. Meteor. Soc., 137, 553-597, 2011.

Draxler, R. R. and Rolph, G. D.: HYSPLIT (HYbrid Single-Particle Lagrangian Integrated Trajectory) Model, available at: http: //www.arl.noaa.gov/HYSPLIT.php (last access: 7 July 2016), NOAA Air Resources Laboratory, College Park, MD, 2013.

Ehn, M., Thornton, J. A., Kleist, E., Sipila, M., Junninen, H., Pullinen, I., Springer, M., Rubach, F., Tillmann, R., Lee, B., LopezHilfiker, F., Andres, S., Acir, I. H., Rissanen, M., Jokinen, T., Schobesberger, S., Kangasluoma, J., Kontkanen, J., Nieminen, T., Kurten, T., Nielsen, L. B., Jorgensen, S., Kjaergaard, H. G., Canagaratna, M., Dal Maso, M., Berndt, T., Petaja, T., Wahner, A., Kerminen, V. M., Kulmala, M., Worsnop, D. R., Wildt, J., and Mentel, T. F.: A large source of low-volatility secondary organic aerosol, Nature, 506, 476-479, 2014.

Foken, T.: Angewandte Meteorologie, Springer, Berlin-Heidelberg, 2006.

Hamed, A., Birmili, W., Joutsensaari, J., Mikkonen, S., Asmi, A., Wehner, B., Spindler, G., Jaatinen, A., Wiedensohler, A., Korhonen, H., Lehtinen, K. E. J., and Laaksonen, A.: Changes in the production rate of secondary aerosol particles in Central Europe in view of decreasing $\mathrm{SO}_{2}$ emissions between 1996 and 2006, 
Atmos. Chem. Phys., 10, 1071-1091, doi:10.5194/acp-10-10712010, 2010.

Hamed, A., Korhonen, H., Sihto, S.-L., Joutsensaari, J., Järvinen, H., Petäjä, T., Arnold, F., Nieminen, T., Kulmala, M., Smith, J. N., Lehtinen, K. E. J., and Laaksonen, A.: The role of relative humidity in continental new particle formation. J. Geophys. Res., 116, D03202, doi:10.1029/2010JD014186, 2011.

Hirsikko, A., Vakkari, V., Tiitta, P., Hatakka, J., Kerminen, V.-M., Sundström, A.-M., Beukes, J. P., Manninen, H. E., Kulmala, M., and Laakso, L.: Multiple daytime nucleation events in semi-clean savannah and industrial environments in South Africa: analysis based on observations, Atmos. Chem. Phys., 13, 5523-5532, doi:10.5194/acp-13-5523-2013, 2013.

Hussein, T., Puustinen, A., Aalto, P. P., Mäkelä, J. M., Hämeri, K., and Kulmala, M.: Urban aerosol number size distributions, Atmos. Chem. Phys., 4, 39-411, doi:10.5194/acp-4-391-2004, 2004.

Iida, K., Stolzenburg, M. R., McMurry, P. H., and Smith, J. N.: Estimating nanoparticle growth rates from sizedependent charged fractions: Analysis of new particle formation events in Mexico City, J. Geophys. Res., 113, D05207, doi:10.1029/2007JD009260, 2008.

Irwin, J. S.: A theoretical variation of the wind profile power-law exponent as a function of surface roughness and stability, Atmos. Environ., 13, 191-194, 1967.

Jokinen, T., Berndt, T., Makkonen, R., Kerminen, V.-M., Junninen, H., Paasonen, P., Startmann, F., Herrmann, H., Guenther, A., Worsnop, D. R., Kulmala, M., Ehn, M., and Sipilä, M.: Production of extremely low-volatile organic compounds from biogenic emissions: measured yields and atmospheric implications, P. Natl. Acad. Sci. USA, 112, 7123-7128, 2015.

Karátson, D. (Ed.): The Land that is Hungary, Pannon Encyclopaedia, Akadémiai Kiadó, Budapest, 2006.

Kerminen, V.-M., Paramonov, M., Anttila, T., Riipinen, I., Fountoukis, C., Korhonen, H., Asmi, E., Laakso, L., Lihavainen, H., Swietlicki, E., Svenningsson, B., Asmi, A., Pandis, S. N., Kulmala, M., and Petäjä, T.: Cloud condensation nuclei production associated with atmospheric nucleation: a synthesis based on existing literature and new results, Atmos. Chem. Phys., 12, $12037-$ 12059, doi:10.5194/acp-12-12037-2012, 2012.

Kiendler-Scharr, A., Wildt, J., Dal Maso, M., Hohaus, T., Kleist, E., Mentel, T. F., Tillmann, R., Uerlings, R., Schurr, U., and Wahner, A.: New particle formation in forests inhibited by isoprene emissions, Nature, 461, 381-384, 2009.

Kulmala, M., Toivonen, A., Mäkelä, J. M., and Laaksonen, A.: Analysis of the growth of nucleation mode particles in Boreal Forest, Tellus B, 50, 449-462, 1998.

Kulmala, M., Vehkamäki, H., Petäjä, T., Dal Maso, M., Lauri, A., Kerminen, V.-M., Birmili, W., and McMurry, P.: Formation and growth rates of ultrafine atmospheric particles: a review of observations, J. Aerosol Sci., 35, 143-176, 2004.

Kulmala, M., Petäjä, T., Mönkkönen, P., Koponen, I. K., Dal Maso, M., Aalto, P. P., Lehtinen, K. E. J., and Kerminen, V.-M.: On the growth of nucleation mode particles: source rates of condensable vapor in polluted and clean environments, Atmos. Chem. Phys., 5, 409-416, doi:10.5194/acp-5-409-2005, 2005.

Kulmala, M., Riipinen, I., Sipilä, M., Manninen, H., Petäjä, T., Junninen, H., Dal Maso, M., Mordas, G., Mirme, A., Vana, M., Hirsikko, A., Laakso, L., Harrison, R. M., Hanson, I., Leung, C.,
Lehtinen, K. E. J., and Kerminen, V.-M.: Toward direct measurement of atmospheric nucleation, Science, 318, 89-92, 2007.

Kulmala, M., Petäjä, T., Nieminen, T., Sipilä, M., Manninen, H. E., Lehtipalo, K., Dal Maso, M., Aalto, P. P., Junninen, H., Paasonen, P., Riipinen, I., Lehtinen, K. E. J., Laaksonen, A., and Kerminen, V.-M.: Measurement of the nucleation of atmospheric aerosol particles, Nat. Protoc., 7, 1651-1667, 2012.

Kulmala, M., Kontkanen, J., Junninen, H., Lehtipalo, K., Manninen, H. E. Nieminen, T., Petäjä, T., Sipilä, M., Schobesberger, S., Rantala, P., Franchin, A., Jokinen, T., Järvinen, E., Äijälä, M., Kangasluoma, J., Hakala, J., Aalto, P. P., Paasonen, P., Mikkilä, J., Vanhanen, J., Aalto, J., Hakola, H., Makkonen, U., Ruuskanen, T., Mauldin III, R. L., Duplissy, J., Vehkamäki, H., Bäck, J., Kortelainen, A., Riipinen, I., Kurtén, T., Johnston, M. V., Smith, J. N., Ehn, M., Mentel, T. F., Lehtinen, K. E. J., Laaksonen, A., Kerminen, V.-M., and Worsnop, D. R.: Direct observations of atmospheric aerosol nucleation, Science, 339, 943-946, 2013.

Laakso, L., Laakso, H., Aalto, P. P., Keronen, P., Petäjä, T., Nieminen, T., Pohja, T., Siivola, E., Kulmala, M., Kgabi, N., Molefe, M., Mabaso, D., Phalatse, D., Pienaar, K., and Kerminen, V.-M.: Basic characteristics of atmospheric particles, trace gases and meteorology in a relatively clean Southern African Savannah environment, Atmos. Chem. Phys., 8, 4823-4839, doi:10.5194/acp-8-4823-2008, 2008.

Mäkelä, J. M., Aalto, P., Jokinen, V., Pohja, T., Nissinen, A., Palmroth, S., Markkanen, T., Seitsonen, K., Lihavainen, H., and Kulmala, M.: Observations of ultrafine aerosol particle formation and growth in boreal forest, Geophys. Res. Lett., 24, 1219-1222, 1997.

Manninen, H. E., Nieminen, T., Asmi, E., Gagné, S., Häkkinen, S., Lehtipalo, K., Aalto, P., Vana, M., Mirme, A., Mirme, S., Hõrrak, U., Plass-Dülmer, C., Stange, G., Kiss, G., Hoffer, A., Töro, N., Moerman, M., Henzing, B., de Leeuw, G., Brinkenberg, M., Kouvarakis, G. N., Bougiatioti, A., Mihalopoulos, N., O’Dowd, C., Ceburnis, D., Arneth, A., Svenningsson, B., Swietlicki, E., Tarozzi, L., Decesari, S., Facchini, M. C., Birmili, W., Sonntag, A., Wiedensohler, A., Boulon, J., Sellegri, K., Laj, P., Gysel, M., Bukowiecki, N., Weingartner, E., Wehrle, G., Laaksonen, A., Hamed, A., Joutsensaari, J., Petäjä, T., Kerminen, V.-M., and Kulmala, M.: EUCAARI ion spectrometer measurements at 12 European sites - analysis of new particle formation events, Atmos. Chem. Phys., 10, 7907-7927, doi:10.5194/acp-10-79072010, 2010.

Mauldin III, R. L., Berndt, T., Sipilä, M., Paasonen, P., Petäjä, T., Kim, S., Kurtén, T., Stratmann, F., Kerminen, V.-M., and Kulmala, M.: A new atmospherically relevant oxidant of sulphur dioxide, Nature, 488, 193-196, 2012.

Merikanto, J., Spracklen, D. V., Mann, G. W., Pickering, S. J., and Carslaw, K. S.: Impact of nucleation on global CCN, Atmos. Chem. Phys., 9, 8601-8616, doi:10.5194/acp-9-8601-2009, 2009.

Mikkonen, S., Romakkaniemi, S., Smith, J. N., Korhonen, H., Petäjä, T., Plass-Duelmer, C., Boy, M., McMurry, P. H., Lehtinen, K. E. J., Joutsensaari, J., Hamed, A., Mauldin III, R. L., Birmili, W., Spindler, G., Arnold, F., Kulmala, M., and Laaksonen, A.: A statistical proxy for sulphuric acid concentration, Atmos. Chem. Phys., 11, 11319-11334, doi:10.5194/acp-11-11319-2011, 2011. 
Németh, Z. and Salma, I.: Spatial extension of nucleating air masses in the Carpathian Basin, Atmos. Chem. Phys., 14, 8841-8848, doi:10.5194/acp-14-8841-2014, 2014.

Nilsson, E. D. and Kulmala, M.: The potential for atmospheric mixing processes to enhance the binary nucleation rate, J. Geophys. Res., 103, 1381-1389, 1998.

Petäjä, T., Mauldin, III, R. L., Kosciuch, E., McGrath, J., Nieminen, T., Paasonen, P., Boy, M., Adamov, A., Kotiaho, T., and Kulmala, M.: Sulfuric acid and $\mathrm{OH}$ concentrations in a boreal forest site, Atmos. Chem. Phys., 9, 7435-7448, doi:10.5194/acp9-7435-2009, 2009.

Pietikäinen, J.-P., Mikkonen, S., Hamed, A., Hienola, A. I., Birmili, W., Kulmala, M., and Laaksonen, A.: Analysis of nucleation events in the European boundary layer using the regional aerosolclimate model REMO-HAM with a solar radiation-driven $\mathrm{OH}-$ proxy, Atmos. Chem. Phys., 14, 11711-11729, doi:10.5194/acp14-11711-2014, 2014.

Riccobono, F., Schobesberger, S., Scott, C., Dommen, J., Ortega, I., Rondo, L., Almeida, J., Amorim, A., Bianchi, F., Breitenlechner, M., David, A., Downard, A., Dunne, E., Duplissy, J., Ehrhart, S., Flagan, R., Franchin, A., Hansel, A., Junninen, H., Kajos, M., Keskinen, H., Kupc, A., Kurten, A., Kvashin, A., Laaksonen, A., Lehtipalo, K., Makhmutov, V., Mathot, S., Nieminen, T., Onnela, A., Petäjä, T., Praplan, A., Santos, F., Schallhart, S., Seinfeld, J., Sipila, M., Spracklen, D., Stozhkov, Y., Stratmann, F., Tome, A., Tsagkogeorgas, G., Vaattovaara, P., Viisanen, Y., Vrtala, A., Wagner, P., Weingartner, E., Wex, H., Wimmer, D., Carslaw, K., Curtius, J., Donahue, N., Kirkby, J., Kulmala, M., Worsnop, D., and Baltensperger, U.: Oxidation products of biogenic emissions contribute to nucleation of atmospheric particles, Science, 344, 717-721, 2014.

Riipinen, I., Pierce, J. R., Yli-Juuti, T., Nieminen, T., Häkkinen, S., Ehn, M., Junninen, H., Lehtipalo, K., Petäjä, T., Slowik, J., Chang, R., Shantz, N. C., Abbatt, J., Leaitch, W. R., Kerminen, V.-M., Worsnop, D. R., Pandis, S. N., Donahue, N. M., and Kulmala, M.: Organic condensation: a vital link connecting aerosol formation to cloud condensation nuclei $(\mathrm{CCN})$ concentrations, Atmos. Chem. Phys., 11, 3865-3878, doi:10.5194/acp-11-38652011, 2011.

Salma, I., Borsós, T., Weidinger, T., Aalto, P., Hussein, T., Dal Maso, M., and Kulmala, M.: Production, growth and properties of ultrafine atmospheric aerosol particles in an urban environment, Atmos. Chem. Phys., 11, 1339-1353, doi:10.5194/acp-111339-2011, 2011.

Salma, I., Borsós, T., Németh, Z., Weidinger, T., Aalto, P., and Kulmala, M.: Comparative study of ultrafine atmospheric aerosol within a city, Atmos. Environ., 92 154-161, 2014.

Salma, I., Füri, P., Németh, Z., Farkas, Á., Balásházy, I., Hofmann, W., and Farkas, Á.: Lung burden and deposition distribution of inhaled atmospheric urban ultrafine particles as the first step in their health risk assessment, Atmos. Environ., 104, 39-49, 2015.

Salma, I., Németh, Z., Weidinger, T., Kovács, B., and Kristóf, G.: Measurement, growth types and shrinkage of newly formed aerosol particles at an urban research platform, Atmos. Chem. Phys., 16, 7837-7851, doi:10.5194/acp-16-7837-2016, 2016.

Sipilä, M., Berndt, T., Petäjä, T., Brus, D., Vanhanen, J., Stratmann, F., Patokoski, J., Mauldin III, R. L., Hyvärinen, A. P., Lihavainen, H., and Kulmala, M.: The role of sulfu- ric acid in atmospheric nucleation, Science, 327, 1243-1246, doi:10.1126/science.1180315, 2010.

Spinoni, J., Szalai, S., Szentimrey T., Lakatos, M., Bihari, Z., Nagy, A., Németh, A., Kovács, T., Mihic, D., Petrovic, P., Kržic, A., Hiebl, J., Auer, I., Milkovic, J., Štepánek, P., Zahradníček, P., Kilar, P., Limanowka, D., Pyrc, R., Cheval, S., Birsan, M. V., Dumitrescu, A., Deák, G., Matei, M., Antolovic, I., Nejedlík, P., Štastný, P., Kajaba, P., Bochniček, O., Galo, D., Mikulová, K., Nabyvanets, Y., Skrynyk, O., Krakovska, S., Gnatiuk, N., Tolasz, R., Antofie, T., and Vogt, J. V.: Climate of the Carpathian Region in the period 1961-2010: climatologies and trends of 10 variables, Int. J. Climatol., 35, 1322-1341, 2014.

Spracklen, D. V., Carslaw, K. S., Kulmala, M., Kerminen, V.-M., Mann, G. W., and Sihto, S.-L.: The contribution of boundary layer nucleation events to total particle concentrations on regional and global scales, Atmos. Chem. Phys., 6, 5631-5648, doi:10.5194/acp-6-5631-2006, 2006.

Weber, R. J., McMurry, P. H., Eisele, F. L., and Tanner, D. J.: Measurement of expected nucleation precursor species and 3-500 nm diameter particles at Mauna Loa Observatory, J. Atmos. Sci., 52, 2242-2257, 1995.

Wehner, B., Wiedensohler, A., Tuch, T. M., Wu, Z. J., Hu, M., Slanina, J., and Kiang, C. S: Variability of the aerosol number size distribution in Beijing, China: new particle formation, dust storms, and high continental background, Geophys. Res. Lett., 31, L22108, doi:10.1029/2004GL021596, 2004.

Weidinger, T., Nagy, Z., Baranka, Gy., Mészáros, R., and Gyöngyösi, A. Z.: Determination of meteorological preprocessor for air quality models in the New Hungarian Standards, Croat. Meteorol. J., 12, 460-464, 2008.

Wiedensohler, A., Birmili, W., Nowak, A., Sonntag, A., Weinhold, K., Merkel, M., Wehner, B., Tuch, T., Pfeifer, S., Fiebig, M., Fjäraa, A. M., Asmi, E., Sellegri, K., Depuy, R., Venzac, H., Villani, P., Laj, P., Aalto, P., Ogren, J. A., Swietlicki, E., Williams, P., Roldin, P., Quincey, P., Hüglin, C., Fierz-Schmidhauser, R., Gysel, M., Weingartner, E., Riccobono, F., Santos, S., Grüning, C., Faloon, K., Beddows, D., Harrison, R., Monahan, C., Jennings, S. G., O’Dowd, C. D., Marinoni, A., Horn, H.-G., Keck, L., Jiang, J., Scheckman, J., McMurry, P. H., Deng, Z., Zhao, C. S., Moerman, M., Henzing, B., de Leeuw, G., Löschau, G., and Bastian, S.: Mobility particle size spectrometers: harmonization of technical standards and data structure to facilitate high quality long-term observations of atmospheric particle number size distributions, Atmos. Meas. Tech., 5, 657-685, doi:10.5194/amt5-657-2012, 2012.

Woo, K. S., Chen, D. R., Pui, D. Y. H., and McMurry, P. H.: Measurement of Atlanta aerosol size distributions: observations of ultrafine particle events, Aerosol Sci. Tech., 34, 75-87, 2001.

Xiao, S., Wang, M. Y., Yao, L., Kulmala, M., Zhou, B., Yang, X., Chen, J. M., Wang, D. F., Fu, Q. Y., Worsnop, D. R., and Wang, L.: Strong atmospheric new particle formation in winter in urban Shanghai, China, Atmos. Chem. Phys., 15, 1769-1781, doi:10.5194/acp-15-1769-2015, 2015.

Yli-Juuti, T., Riipinen, I., Aalto, P. P., Nieminen, T., Maenhaut, W., Janssens, I. A., Claeys, M., Salma, I., Ocskay, R., Hoffer, A., Imre, K., and Kulmala, M.: Characteristics of new particle formation events and cluster ions at K-puszta, Hungary, Boreal Environ. Res., 14, 683-698, 2009. 